\title{
Opini Publik di Media Sosial: Analisis Isi Opini Kandidat Ahok-Djarot dan Anies-Sandi di Twitter
}

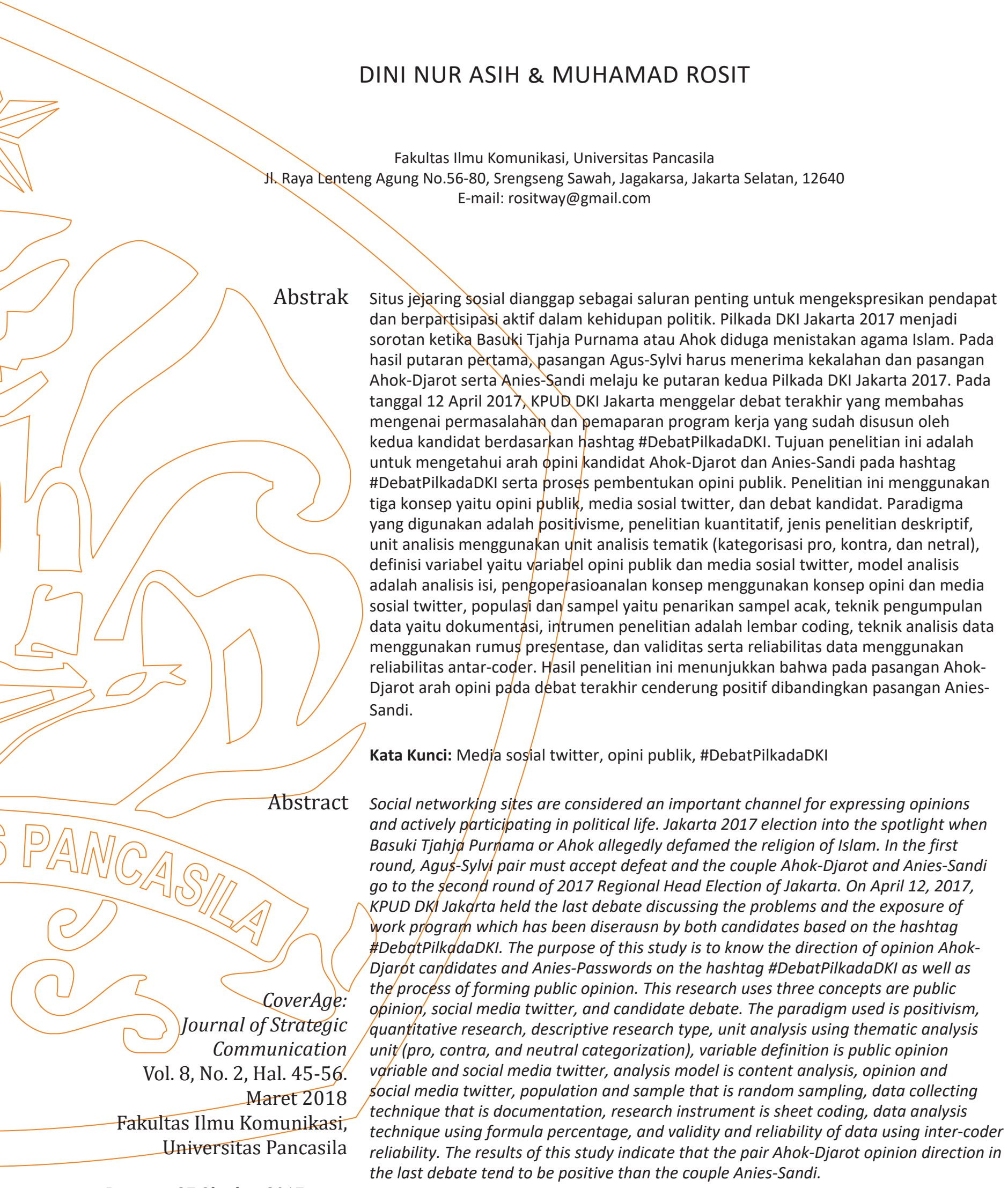




\section{PENDAHULUAN}

Media sosial merupakan salah satu wadah untuk menyuarakan pendapat. Partisipasi aktif muncul ketika terdapat isu yang menarik untuk dibahas maka muncul pendapat-pendapat yang beragam. Pembentukan opini publik dimulai dari pengertian dan pengetahuan, lalu terbentuklah sikap dan pendapat (setuju atau tidak setuju), dan pelaksanaan.

Dengan adanya media sosial, masyarakat bisa dengan leluasa menyampaikan apa saja tentang pendapat mereka tentang sesuatu hal baik yang bersifat pribadi maupun kelompok. Pentingnya media sosial salah satunya dalam ranah politik sebagian didasarkan pada bagaimana kita mengonsumsi dan memahami informasi (Gainous\&Wagner, 2014:106).

Menggunakan media sosial untuk mengekspresikan opini dan sikapnya. Menggalang solidaritas lewat petisi, dukungan di media sosial hingga menciptakan media sosial yang bisa memengaruhi agenda media konvensional hingga agenda politik. Penggalangan dukungan hingga perang opini di twitter menjadi hal yang biasa (Subiakto\&lda, 2012:73).

Menurut Juditha (2014:8), mereka mengeluarkan pendapat melalui kekuatan media sosial. Dahulu, untuk mengeluarkan suatu opini atau pendapat yang berbeda saja dengan penguasa atau pemerintah, hal tersebut sangat mustahil terjadi. Munculnya opini publik muncul dari alat kontrol sosial, termasuk manipulasi lambang yang menarik, propaganda, hubungan masyarakat, dan pengelolaan berita, kelompok di dalam dan di luar pemerintahan mencoba, dan sering berhasil memengaruhi sentimen perseorangan dan organisasi pemerintahannya (Nimmo, 2010:30).

Pilkada DKI Jakarta 2017 ramai diperbincangkan di media sosial, dimulai pada saat seorang dosen salah satu universitas swasta di Jakarta bernama Buni Yani yang mengunggah video pidato Gubernur Basuki Tjahja Purnama atau Ahok di Kepulauan Seribu di akun facebook pribadinya. Unggahan Buni Yani tersebut menjadi viral di berbagai media sosial, termasuk di twitter.

Sifat media sosial yang bebas dan cenderung tidak terkendali sehingga tanpa sadar terkadang pengguna twitter dengan bebas juga menyerang privasi seseorang. Dalam kasus dugaan penistaan agama yang dituduhkan kepada Ahok, terbentuklah opini-opini pengguna media sosial khususnya twitter, baik opini positif, netral maupun negatif. Isu SARA menjadi isu yang masih banyak diperbincangkan oleh masyarakat.

Dalam konteks politik, menurut Gainous \& Wagner (2014:22-23), pengguna media sosial khususnya twitter pada umumnya lebih menyukai pemimpin politik pilihan dan persepsi mereka yang bersifat positif. Dengan demikian warga dapat memilih sendiri jaringan yang mendukung para pemimpin politik ini dan orang-orang yang mereka percaya. Aktor politik pun juga memiliki cara yang sangat ampuh untuk membentuk pemahaman kognitif pengguna media sosial, mereka dapat membuat pengguna lebih cenderung menerima informasi baru.

Kampanye putaran kedua dimulai pada 7 Maret 2017 dan berakhir pada tanggal 15 April 2017. Lalu, debat terakhir putaran ke-2 dilaksanakan pada tanggal 12 April 2017. Debat tersebut diselenggarakan di Hotel Bidakara, Jakarta Selatan. "Dari Masyarakat Jakarta untuk Jakarta" merupakan tema debat terakhir yang diselenggarakan oleh KPUD DKI Jakarta. Sentimen publik khususnya di media sosial khususnya di twitter terkait debat terakhir sangat tinggi. Muncul hashtag \#DebatPilkadaDKI yang mana hashtag tersebut menjadi wadah untuk para pengguna twitter memberikan opini mereka terhadap debat tersebut.

Penyebab hashtag \#DebatPilkadaDKI muncul dikarenakan tema debat terakhir yang diusung oleh KPUD DKI Jakarta menarik perhatian para netizen (panggilan untuk para pengguna media sosial) khususnya di twitter serta debat terakhir dinilai penting untuk memprediksi siapa menjadi Gubernur dan Wakil Gubernur DKI Jakarta periode 2017-2022. Para aktor politik yang berafiliasi dengan masing-masing pasangan calon berpartisipasi dalam hashtag tersebut, mereka pun juga berusaha untuk memberikan pengaruh kepada para pengguna media sosial khususnya di twitter untuk memilih pasangan calon nomor dua atau nomor tiga.

Berdasarkan latar belakang dan identifikasi masalah tersebut, maka batasan masalah dari penelitian ini adalah untuk mengetahui arah opini yang didapatkan pasangan Ahok-Djarot dan AniesSandi berdasarkan hashtag \#DebatPilkadaDKI di media sosial pada debat terakhir tanggal 12 April 2017. Tujuan penelitian ini adalah untuk mengetahui arah opini pasangan calon nomor dua Ahok-Djarot pada debat terakhir tanggal 12 April 2017, dan untuk mengetahui arah opini pasangan calon nomor tiga Anies-Sandi pada debat terakhir tanggal 12 April 
2017, serta untuk mengetahui proses pembentukan opini publik sepanjang Pilkada DKI Jakarta 2017.

\section{TINJAUAN PUSTAKA}

\section{Opini Publik}

Opini publik menurut Arifin (2008:10) adalah suatu pendapat yang sama dan dinyatakan oleh banyak orang yang diperoleh melalui diskusi yang intensif sebagai jawaban atas pertanyaan dan permasalahan yang menyangkut kepentingan umum. Permasalahan itu tersebar luas melalui media massa. Pendapat rata-rata individu-individu itu memberi pengaruh terhadap orang banyak dalam waktu tertentu. Pengaruh itu dapat sifat positif, netral bahkan negatif. Sedangkan menurut Correia \& Maia (2011:43), opini publik dibentuk oleh sebagian besar subyek dari perhatian. Tugas pengaturan isu agenda publik diambil alih oleh politisi dan jurnalis.Isu tersebut merupakan isu yang masuk akal untuk dibicarakan tanpa adanya suatu penyensoran yang datang dari komunikasi itu sendiri.

Menurut Nimmo (2010:24), pembentukan opini adalah proses empat tahap yang melibatkan kesalinglingkupan aspek personal, sosial, dan politik. Nimmo (2010) mengungkapkan proses empat tahap pembentukan opini yaitu:

1. Pertikaian yang mempunyai potensi menjadi isu

2. Kepemimpinan politik

3. Interpretasi personal dan pertimbangan sosial

4. Kesediaan mengungkapkan opini pribadi di depan umum

Nimmo (2010:25) pun menjelaskan empat karakteristik opini publik, yaitu:

1. Terdapat isi, arah dan intensitas yang ada di dalam opini publik. Ciri-ciri ini menyangkut opini publik tentang tokoh politik (biasanya pejabat pemerintah dan kandidat tetapi juga jenis lain seperti pemimpin politik).

2. Kontroversi menandai opini publik artinya sesuatu yang tidak disepakati seluruh rakyat.

3. Opini publik mempunyai volume berdasarkan kenyataan bahwa kontroversi itu menyentuh semua orang yang merasakan konsekuensi langsung dan tak langsung meskipun mereka bukan pihak yang bertikai.

4. Opini publik bersifat tetap.

\section{Media Sosial Twitter}

Media sosial adalah media baru dan pada tahap ini, individu senang menggunakan serta menikmati isi yang tersedia di internet dan media sosial. Mereka juga lebih antusias untuk menguji aplikasi yang berbeda yang disediakan oleh teknologi canggih. Sebab banyak kehebohan yang terkait dengan penggunaan media sosial, orang umumnya percaya apa yang datang dari media ini (Patrut \& Patrut, 2014:365).

Salah satu media sosial saat ini adalah Twitter. Didirikan oleh Jack Dorsey dan sebuah asosiasi di San Francisco pada tahun 2006, twitter membawa dua subkultur secara bersamaan. Twitter merupakan sarana gaya hidup urban bagi teman-teman untuk saling memberikan update tentang keberadaan dan kegiatan mereka (Weller, et.al., 2014: 10).

Di dalam fitur twitter, terdapat fitur bernama Hashtag. Hashtag biasanya digunakan untuk menandai tweet atau cuitan yang relevan dengan topik tertentu dan membuatnya lebih mudah ditemukan oleh pengguna lain. Dimasukkannya hashtag topikal dalam cuitan artinya pesan tersebut memiliki potensi untuk mencapai jauh di luar jumlah yang ada pengguna pengikut (Weller, et.al, 2014:17).

Twitter dapat mendorong sentimen publik dan mengatur kemarahan publik, simpati, sukacita, dan ketakutan. Dalam banyak kasus, twitter memungkinkan seseorang untuk memiliki rasa keahlian dan jati diri. sentimen publik dapat dimobilisasi untuk mendukung demokrasi, tetapi sentimen tersebut juga dapat melayani politik represif yang merugikan aktivitas demokratis (Fortner \& Fackler, 2014:521).

\section{Debat Kandidat}

Menurut Perloff (2008:388), kandidat yang mengikuti sebuah debat menggunakan sejumlah strategi retorika selama debat. Strategis pertama dari debat politik adalah untuk mengartikulasikan suatu visi atau mengungkapkan tema debat secara menyeluruh. Kandidat menggunakan ucapan pembuka dan penutupan mereka untuk mengungkapkan tema debat, dan menggantungkan jawaban mereka atas pertanyaan spesifik untuk memperkuatnya. Debat yang disiarkan di televisi adalah sebuah kesempatan untuk menciptakan citra diri mereka sebagai pemimpin berpengalaman yang siap menghadapi krisis yang dihadapi sebuah negara ataupun daerah.

Strategi kedua yang digunakan kandidat adalah bersikap negatif, mengkritik gagasan lawan atau mencoba untuk melemparkan pendapat pada gaya 
kepemimpinan lawan, kompetensi, atau karakter. Mengkritik posisi lawan adalah strategi debat klasik. Strategi terakhir adalah kandidat menggunakan sejumlah taktik persuasi verbal dan nonverbal untuk memaksimalkan kredibilitas mereka. Meskipun bukan senjata terpenting dalam perdebatan, namun kemampuan komunikasi nonverbal dapat meningkatkan kredibilitas kandidat.

Perdebatan pun juga membantu memperkuat sikap pemilih, menggabungkan pemikiran dan perasaan bersama-sama tentang kandidat ke dalam keseluruhan yang lebih kohesif. Pemilih pasti memiliki perasaan campur aduk tentang kandidat, bahkan kandidat yang mereka dukung. Perdebatan membantu meningkatkan tingkat konsistensi kognitif yang lebih tinggi di antara batasan masalah, sikap terhadap kandidat, dan niat untuk memilih (Perloff, 2008:400).

\section{METODE}

\section{Unit Analisis}

Unit tematik secara sederhana berbicara mengenai "teks berbicara tentang apa atau mengenai apa" (Eriyanto, 2011:84). Tematik dari suatu teks dapat dilihat dari subjek yang terdapat dalam teks.Jika dalam teks terdapat tiga subjek, berarti dalam teks tersebut terdapat tiga tema. Peneliti menggunakan unit analisis tematik dengan tiga kategorisasi yaitu opini pro atau positif, kontra atau negatif serta netral. Peneliti menggunakan cuitan-cuitan atau opini berdasarkan hashtag \#DebatPilkadaDKI yang muncul pada debat terakhir pada tanggal 12 April 2017 untuk melihat arah opini yang didapatkan Ahok-Djarot dan Anies-Sandi.

Tabel 1. Unit tematik

\begin{tabular}{cl}
\hline $\begin{array}{c}\text { Kategori } \\
\text { Kecenderungan/ } \\
\text { Sikap Isi Pesan }\end{array}$ & \multicolumn{1}{c}{ Definisi } \\
\hline Pro & $\begin{array}{l}\text { Pendapat atau opini yang } \\
\text { mendukung bersifat positif } \\
\text { atau dengan kata-kata } \\
\text { pujian. } \\
\text { Kontra }\end{array}$ \\
& $\begin{array}{l}\text { Pendapat atau opini } \\
\text { yang tidak mendukung } \\
\text { bersifat negatif bahkan } \\
\text { mengeluarkan kata-kata } \\
\text { hinaan. } \\
\text { Pendapat atau opini yang } \\
\text { secara tersirat mendukung } \\
\text { dan tidak mendukung. }\end{array}$ \\
\hline
\end{tabular}

(Sumber: Data peneliti)

\section{Definisi Variabel Penelitian}

Variabel yang peneliti gunakan adalah variabel opini, publik, media sosial dantwitter. Adapun definisi variabel sebagai berikut:

1. Opini: Dalam pengertian epistemologis, opini menunjukkan suatu cara inferior tertentu dan sedikit banyak untuk mengetahui, membedakan masalah penghakiman dari suatu hal yang dikenal sebagai fakta atau ditegaskan pada kepercayaan (Donsbach \& Traugott, 2008:11).

2. Publik : Publik mengacu pada kepentingan bersama dan kebaikan bersama, bukan dalam arti akses (milik) melainkan dalam arti mewakili (yaitu atas nama) seluruh rakyat (Donsbach \& Traugott, 2008:12).

3. Media Sosial : Media sosial adalah media yang memungkinkan seseorang untuk berbagi konten, berita, foto dll dengan orang lain (Taprial\&Kanwar, 2012:1).

4. Twitter: Diciptakan oleh Jack Dorsey pada buIan Maret 2006. Twitter mengizinkan penggunanya untuk mengirim dan membaca posting berbasis teks hingga 140 karakter yang dikenal sebagai "tweets"atau cuitan secara real-time yang mendapatkan popularitas di seluruh dunia dengan lebih dari 300 juta pengguna sejak 2011 (Taprial \& Kanwar, 2012:23).

\section{Model Analisis}

Peneliti menggunakan model analisis isi kuantitatif. Menurut Neuman (2016:52), analisis isi kuantitatif adalah teknik untuk menelaah isi atau informasi dan simbol yang terdapat dalam dokumen tertulis atau media komunikasi lain. Lalu, isi dari medium komunikasinya secara sistematis dicatat dan dianalisis.Analisis isi bersifat non-reaktif, artinya objek penelitian tidak sadar bahwa informasi mengenai mereka merupakan bagian dari penelitian.

\section{Operasional Konsep}

Menurut Eriyanto (2011:175), konsep bertujuan untuk menggambarkan atau mengabstraksikan suatu gejala. Dengan adanya konsep, para ahli dapat berbicara tentang gejala yang sama, melakukan replikasi penelitian, dan memperbarui penelitian yang satu dengan yang lain. Konsep yang digunakan oleh peneliti adalah konsep Opini Publik dan Media Sosial Twitter. 
Tabel 2. Konsep Opini

\begin{tabular}{cl}
\hline Opini & \multicolumn{1}{c}{ Definisi } \\
\hline Pro & $\begin{array}{l}\text { Bila pernyataan atau pendapat/opini } \\
\text { yang ditampilkan dalam cuitan-cuitan }\end{array}$ \\
& $\begin{array}{l}\text { mendukung atau positif yaitu memuji, } \\
\text { menyanjung, dan menyetujui sebuah isu. }\end{array}$ \\
Kontra & $\begin{array}{l}\text { Bila pernyataan atau opini yang ditampilkan } \\
\text { dalam cuitan-cuitan tidak mendukung } \\
\text { yaitu dengan mencela, meremehkan, dan } \\
\text { menolak sebuah isu. }\end{array}$ \\
Netral & $\begin{array}{l}\text { Bila pernyataan atau opini yang ditampilkan } \\
\text { cuitan-cuitan tidak bersikap memihak } \\
\text { terhadap sebuah isu. }\end{array}$
\end{tabular}

(Sumber: Data peneliti)

Tabel 3. Konsep Media Sosial

\begin{tabular}{cl}
\hline Media Sosial & \multicolumn{1}{c}{ Definisi } \\
\hline Apa & $\begin{array}{l}\text { Isu yang memicu pembicaraan yang } \\
\text { kontroversial. }\end{array}$ \\
Siapa & $\begin{array}{l}\text { Seseorang yang memicu isu tertentu } \\
\text { yang memicu kontroversial. }\end{array}$ \\
\hline
\end{tabular}

(Sumber: Juditha, 2014:64)

\section{Populasi dan Sampel}

Penentuan sampel pada penelitian ini menggunakan metode penarikan sampel acak. Penarikan sampel acak (probability sampling) adalah teknik penarikan sampel yang menggunakan hukum probabilitas, di mana memberikan kesempatan atau peluang yang sama kepada anggota populasi untuk terpilih sebagai sampel (Eriyanto, 2011:115).

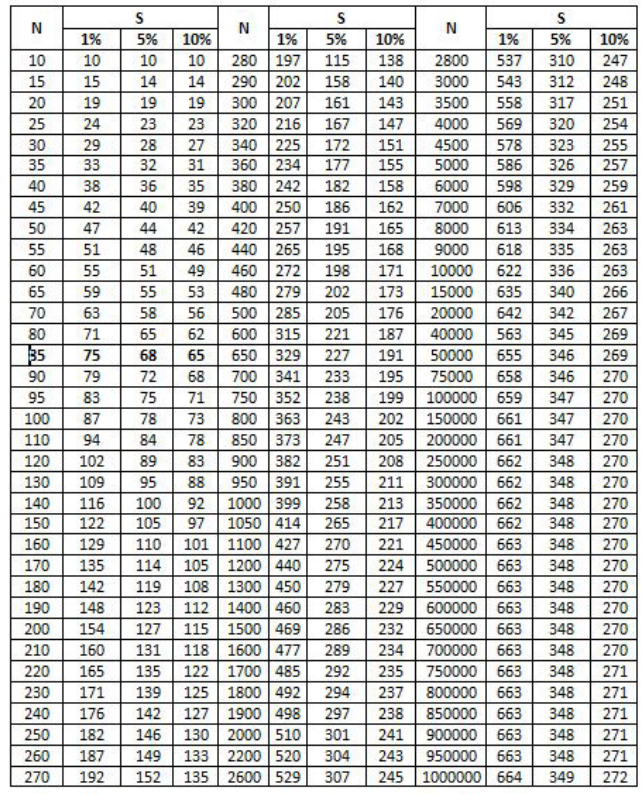

Gambar 1. Rumus Stephen Isaac dan Willam B. Michael
Populasi yang peneliti gunakan merupakan semua cuitan yang dimuat pada media jejaring sosial yang mana menggunakan hashtag\#DebatPilkadaDKI yaitu debat terakhir yang diselenggarakan oleh KPUD DKI Jakarta. Unit sampel yang peneliti gunakan adalah seluruh tweet atau cuitan dengan hashtag \#DebatPilkadaDKI pada tanggal 12 April 2017. Peneliti memperoleh populasi sebesar 400 cuitan. Berdasarkan rumus Stephen Isaac dan William B. Michael, N sebesar 400 berdasarkan tingkat kepercayaan $5 \%$, peneliti mengambil sampel sebanyak 186 cuitan.

\section{Teknik Pengumpulan Data}

Peneliti menggunakan data primer yaitu berupa dokumentasi. Dokumentasi adalah jenis metode pengumpulan data yang bertujuan untuk menggali data-data masa lampau secara sistematis dan objektif. Dokumentasi yang peneliti ambil yaitu screen captured cuitan yang terdapat di twitter terkait \#DebatPilkadaDKI. Peneliti mengumpulkan screen captured berupa cuitan-cuitan para pengguna di twitter. Peneliti mengambil data pada tanggal 12 April 2017.

\section{Instrumen Penelitian}

Instrumen penelitian yang peneliti pilih untuk penelitian ini adalah lembar coding (coding sheet). Menurut Eriyanto (2011:221), lembar coding adalah alat yang dipakai untuk menghitung atau mengukur aspek tertentu dari isi media. Lembar coding memuat aspek-aspek apa saja yang ingin kita lihat dalam analisis isi. Kategori yang dipakai dalam penelitian ini disajikan dalam sebuah lembar coding baik dicetak maupun disajikan dalam sebuah file. Kategori yang peneliti pakai dalam penelitian ini adalah kategori kecenderungan isu pesan yaitu pro, kontra, dan netral.

\section{Teknik Analisis Data}

Peneliti melakukan analisis data dengan cara mengategorisasikan kumpulan opini yang telah diperoleh dari media sosial twitter pada tanggal 12 April 2017 terkait opini pada hashtag \#DebatFinalPilkadaDKI kandidat Ahok-Djarot dan Anies-Sandi, lalu memasukkan hasilnya kedalam tabulasi data sederhana.

Menurut Eriyanto (2011:281), dalam analisis isi alat ukur yang dipakai adalah lembar coding (coding sheet). Kita harus memastikan bahwa lembar coding yang akan kita pakai adalah alat ukur yang terpercaya. Dalam pengisian lembar coding, penulis akan dibantu 
oleh orang lain (coder) yang ditunjuk untuk menjadi pembanding atau hakim guna mengukur ketepatan penilaian peneliti terhadap kategori pada unit analisis yang telah ditentukan dalam penelitian ini.

\section{Validitas dan Reliabilitas}

Pengecakan keabasahan data pada penelitian ini menggunakan validitas muka (face validity). Menurut Eriyanto (2011:260), validitas ini berkaitan dengan apakah alat ukur yang dipakai memang mengukur konsep yang ingin diukur. Validitas muka (face validity) mengecek dan memastikan bahwa ukuran yang dipakai sesuai dengan apa yang ingin diukur. Peneliti menggunakan reliabilitas antar-coder.

Peneliti menggunakan formula Holsti untuk menghitung derajat reliabilitas antar-coder, angka reliabilitas minimum yang ditoleransi adalah 0,7 atau 70\%. Artinya, jika hasil perhitungan menunjukkan angka reliabilitas di atas 0,7 berarti alat ukur ini benar-benar teruji (Eriyanto, 2011:290). Rumus untuk menghitung reliabilitas ini adalah sebagai berikut:

$$
\text { Reliabilitas Antar }- \text { Coder }=\frac{2 \mathrm{M}}{\mathrm{NI}+\mathrm{N} 2} .
$$

Keterangan:

$\mathrm{M}$ : Jumlah coding yang sama (disetujui oleh masingmasing coder)

N1 : Jumlah coding yang dibuat oleh coder 1

N2 : Jumlah coding yang dibuat oleh coder 2

Dalam penelitian ini, yang bertindak sebagai coder adalah peneliti sendiri sebagai peneliti, coder 1 adalah Rachmi Dewi P, coder 2 adalah Muhammad Ibrahim. Setelah dilakukan uji reliabilitas, oleh peneliti, coder 1 dan coder 2. Maka berdasarkan penafsiran yang dikemukakakn formula Holsti di mana untuk masing-masing kategorinya sebagai berikut :

Berdasarkan hasil perhitungan dengan menggunakan rumus reliabilitas coder formula Holsti di atas, hasil tersebut menunjukkan bahwa kesepakatan hubungan antar pengkoding (coder) untuk kategorisasi kecenderungan/sikap opini hashtag \#DebatPilkadaDKI masing-masing 1 atau $100 \%$. Maka berdasarkan identifikasi dikemukakan oleh R. Holsti kategori tersebut memiliki korelasi yang sah karena memiliki indeks relibilitas di atas 0,7 atau $70 \%$.

\section{HASIL DAN PEMBAHASAN}

Peneliti menggunakan rumus persentase untuk mengetahui intensitas opini kedua kandidat yaitu Ahok-Djarot dan Anies-Sandi berdasarkan kategori kecenderungan atau sikap opini yaitu pro, kontra dan netral. Berdasarkan Sugiyono (2011) dalam Husni (2013:66), rumus persentase sebagai berikut:

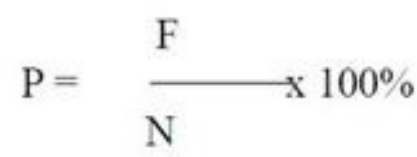

Keterangan:

$P$ : Persentase

$\mathrm{F}:$ Frekuensi

$\mathrm{N}$ : Jumlah Data

Hasil Penelitian

Tabel 4. Uji Reabilitas

\begin{tabular}{|c|c|c|c|c|c|c|}
\hline \multirow{4}{*}{$\begin{array}{l}\text { Antar } \\
\text { Coder }\end{array}$} & \multicolumn{6}{|c|}{ Kategori Kecenderungan/Sikap Opini Pada Hashtag \#DebatPilkadaDKI } \\
\hline & \multirow{2}{*}{\multicolumn{2}{|c|}{$\begin{array}{c}\text { Pro } \\
N=73\end{array}$}} & \multirow{2}{*}{\multicolumn{2}{|c|}{$\begin{array}{l}\text { Kontra } \\
\mathrm{N}=99\end{array}$}} & \multirow{2}{*}{\multicolumn{2}{|c|}{$\begin{array}{l}\text { Netral } \\
\mathrm{N}=14\end{array}$}} \\
\hline & & & & & & \\
\hline & Sepakat & $\begin{array}{c}\text { Tidak } \\
\text { Sepakat }\end{array}$ & Sepakat & $\begin{array}{c}\text { Tidak } \\
\text { Sepakat }\end{array}$ & Sepakat & $\begin{array}{c}\text { Tidak } \\
\text { Sepakat }\end{array}$ \\
\hline $\mathrm{C} 1$ & 73 & 0 & 99 & 0 & 14 & 0 \\
\hline $\mathrm{C} 2$ & 73 & 0 & 99 & 0 & 14 & 0 \\
\hline
\end{tabular}

(Sumber: Data Pengolahan Peneliti) 
Berdasarkan tabel 5, keseluruhan cuitan pengguna twitter menggunakan hashtag \#DebatPilkadaDKI dibagi menjadi cuitan pro, kontra, dan netral. Cuitan pro atau positif sebanyak 73 cuitan dengan persentase $39,24 \%$, kontra atau negatif sebanyak 99 cuitan dengan persentase $53,22 \%$ dan netral sebanyak 14 cuitan dengan persentase 7,52\%.

Berdasarkan tabel 6 , hasil penelitian opini keseluruhan pasangan nomor 2 dari 186 cuitan pengguna twitter adalah 66 cuitan dengan pembagian 40 opini pro atau mendukung sebesar $21,50 \%$. Sedangkan 26 opini kontra atau tidak mendukung sebesar $13,97 \%$ dan tidak ada opini netral yang dilontarkan para pengguna twitter.
Di dalam keseluruhan isi pesan atau opini para pengguna twitter terdapat opini-opini yang mengandung SARA. Hasil penelitian pada tabel di atas menunjukkan opini pro atau mendukung SARA pasangan calon nomor 2 yaitu 8 dari 26 cuitan opini dengan persentase sebesar $4,30 \%$. Sedangkan opini kontra atau tidak mendukung yaitu 5 dari 186 opini dengan persentase sebesar $2,68 \%$.

Adapun opini-opini mengenai program kerja yang telah dilaksanakan maupun sedang disusun pasangan Ahok-Djarot, dapat dilihat pada tabel di atas bahwa opini pro tersebut berjumlah 5 dari 40 opini dengan persentase sebesar $2,68 \%$. Sama

Tabel 5.

Persentase keseluruhan cuitan hashtag \#DebatPilkadaDKI

\begin{tabular}{cccc}
\hline No & Cuitan Keseluruhan & Frekuensi & Persentase \\
\hline 1. & Pro & 73 & $39,24 \%$ \\
2. & Kontra & 99 & $53,22 \%$ \\
3. & Netral & 14 & $7,52 \%$ \\
\hline
\end{tabular}

(Sumber: Data Pengolahan Peneliti)

Tabel 6.

Persentase opini keseluruhan Ahok-Djarot

\begin{tabular}{cccc}
\hline No & Opini Keseluruhan & Frekuensi & Persentase \\
\hline 1. & Pro & 40 & $21,50 \%$ \\
2. & Kontra & 26 & $13,87 \%$ \\
3. & Netral & 0 & 0 \\
\hline
\end{tabular}

(Sumber: Data Pengolahan Peneliti)

Tabel 7.

Persentase opini SARA Ahok-Djarot

\begin{tabular}{cccc}
\hline No & Opini SARA & Frekuensi & Persentase \\
\hline 1. & Pro & 8 & $4,30 \%$ \\
2. & Kontra & 5 & $2,68 \%$ \\
3. & Netral & 0 & 0 \\
\hline
\end{tabular}

(Sumber: Data Pengolahan Peneliti)

Tabel 8.

Persentase opini program Kerja Ahok-Djarot

\begin{tabular}{cccc}
\hline No & Opini Program Kerja & Frekuensi & Persentase \\
\hline 1. & Pro & 5 & $2,68 \%$ \\
2. & Kontra & 5 & $2,68 \%$ \\
3. & Netral & 0 & 0 \\
\hline
\end{tabular}

(Sumber: Data Pengolahan Peneliti) 
Tabel 9.

Persentase opini Keseluruhan Anies-Sandi

\begin{tabular}{cccc}
\hline No & Opini Keseluruhan & Frekuensi & Persentase \\
\hline 1. & Pro & 33 & $17,74 \%$ \\
2. & Kontra & 73 & $39,24 \%$ \\
3. & Netral & 0 & 0 \\
\hline
\end{tabular}

(Sumber: Data Pengolahan Peneliti)

Tabel 10.

Persentase opini program kerja Anies-Sandi

\begin{tabular}{cccc}
\hline No & Opini Program Kerja & Frekuensi & Persentase \\
\hline 1. & Pro & 7 & $3,76 \%$ \\
2. & Kontra & 40 & $21,50 \%$ \\
3. & Netral & 0 & 0 \\
\hline
\end{tabular}

(Sumber: Data Pengolahan Peneliti)

halnya dengan cuitan yang mendukung, opini kontra menunjukkan persentase sebesar $2,68 \%$.

Berdasarkan hasil penelitian di atas, keseluruhan opini pasangan kandidat Anies-Sandi memperoleh 106 opini. 33 opini pro atau mendukung dengan persentase sebesar $17,74 \%$. Sedangkan opini kontra berjumlah 73 dengan persentase $39,24 \%$.

Hasil temuan dari opini mengenai program kerja yang didapatkan Anies-Sandi, opini yang mendukung dari 33 opini terdapat 7 opini yang mendukung program kerja mereka dengan persentase sebesar $3,76 \%$. Sedangkan persentase opini yang tidak mendukung program kerja yang telah disusun oleh pasangan kandidat Anies-Sandi dari 73 opini, 40 opini tidak mendukung dengan persentase sebesar $21,50 \%$.

Beberapa cuitan pengguna twitter menuliskan bahwa mereka memilih Anies-Sandi karena keduanya beragama Islam. Indonesia merupakan salah satu negara yang menganut sistem kepemimpinan demokrasi yang artinya negara yang lebih mengedepankan persamaan hak dan kewajiban agar semua rakyatnya turut andil dalam memerintah dan mengurus tatanan kenegaraan dengan perantara wakilnya (pemimpin).

Berdasarkan keseluruhan opini yang didapatkan Anies-Sandi tidak ditemukan opini-opini SARA. Namun, kedatangan Anies Baswedan ke markas FPI (Front Pembela Islam) pada tanggal 11 Januari 2017 menjadi pembicaraan pengguna twitter dan banyak masyarakat yang menyayangkan sikap Anies. Dilansir dari www.kompas.com, Anies mengatakan bahwa ia diundang oleh Rizieq Shihab. la melanjutkan bahwa Jakarta membutuhkan kepemimpinan yang bisa merangkul dan berdamai dengan semua kalangan.

Dua program kerja Anies-Sandi yang menjadi sorotan yaitu OK OCE dan rumah tanpa DP 0 persen. OK OCE atau One Kecamatan One Center For Entrepreneurship merupakan nama program kewirausahaan yang diusung oleh pasangan AniesSandi. Selain OK OCE, pasangan Anies-Sandi juga mengusung OK TRIP yang merupakan program untuk transportasi, penumpang cukup mengeluarkan uang Rp 5000 untuk menaiki Kopaja, Metromini, dan angkutan umum lainnya.

Dari banyaknya opini pro atau positif dan kontra atau negatif para pengguna twitter dengan mencantumkan hashtag \#DebatPilkadaDKI, terdapat opini-opini netral yang dilontarkan oleh para pengguna. Opini-opini netral yang beredar kebanyakan mengharapkan Gubenur dan Wakil Gubenur DKI Jakarta 2017 terpilih mampu membangun Jakarta menjadi lebih baik.

Banyaknya opini yang beredar selama Pilkada DKI Jakarta 2017 dimulai dari putaran pertama sampai putaran kedua tidak serta merta muncul begitu saja. Jika dikaitkan dengan 4 tahap pembentukan opini publik, pembahasan yang dapat dijabarkan yaitu pertama, pertikaian yang mempunyai potensi menjadi isu. Dalam konteks Pilkada DKI Jakarta 2017, isu yang pertama kali muncul dan memunculkan kontroversi, yaitu saat Ahok menyampaikan 
pidatonya di Kepulauan Seribu, banyak masyarakat yang percaya bahwa Ahok menistakan agama Islam. Lalu, muncul aksi-aksi mengatasnamakan "Bela Islam" yang tujuannya agar Ahok diproses hukum dan dimasukkan ke penjara.

Kedua, kepemimpinan politik. Kiprah Basuki Tjahja Purnama dibidang politik tidak bisa diragukan lagi. Ahok menggantikan Joko Widodo sebagai Gubernur DKI Jakarta pada tahun 2014. Sosok Ahok yang tegas dan memiliki sifat yang keras memang mendapatkan tanggapan yang beragam dari masyarakat Jakarta. "Kasus Al-Maidah 51" yang menjerat dirinya dapat menjadi batu loncatan bagi musuh-musuhnya untuk menjatuhkan Ahok dalam persaingan bursa pemimpin di Ibukota DKI Jakarta ini.

Ketiga, interpretasi personal dan pertimbangan sosial.Kasus dugaan penistaan agama Islam yang dilakukan oleh Basuki Tjahja Purnama mendapatkan kekecewaan yang sangat besar dari masyarakat Jakarta bahkan di seluruh Indonesia. Indonesia dengan mayoritas masyarakatnya beragama Islam sontak melimpahkan kekecewaan mereka dengan membuat opini di akun media sosial mereka khususnya. Namun, ada sebagian masyarakat yang tidak meyakini kalau Ahok bersalah dalam kasus dugaan penistaan agama. Mereka yang tidak meyakini hal tersebut berpendapat bahwa Ahok hanya berada di permainan politik yang kejam dan hal tersebut merupakan strategi lawan politik untuk menjatuhkan dirinya.

Terakhir, kesediaan mengungkapkan opini pribadi di depan umum. Sifat media sosial yang bebas dan mudah diakses membuat para penggunanya dengan leluasa mengeluarkan pendapat mereka. Opiniopini yang menggunakan hashtag \#DebatPilkadaDKI pun beragam, dapat dilihat beberapa opini yang menyuarakan kebencian dan penghinaan SARA khususnya yang menimpa pasangan Ahok-Djarot.

Jika dikaitkan dengan konsep debat kandidat yang dikemukakan oleh Perloff (2008:388), terdapat tiga strategi dalam sebuah debat dan strategistrategi tersebut juga menjadi faktor penting dalam kemenangan salah satu kandidat. Pertama, para peserta debat dapat mengartikulasikan suatu visi atau mengungkapkan tema debat secara menyeluruh dengan sangat baik. Kedua, peserta debat mengkritik posisi lawan. Terakhir, perserta debat melakukan strategi dengan melakukan komunikasi verbal maupun non-verbal.

Dalam konteks debat terakhir Pilkada DKI Jakarta 2017, strategi-strategi tersebut sudah diterapkan oleh kedua kandidat, yaitu Ahok-Djarot dan Anies-Sandi. Namun, hanya salah satu kandidat yang berhasil menerapkan strategi-strategi tersebut. Berdasarkan temuan penelitian, pasangan AhokDjarot memenangkan pertarungan pada debat terakhir dengan memperoleh opini positif sebesar 21,5\% pada tabel 10.

Jika dikaitkan dengan strategi debat politik Perloff (2008), strategi pertama menjelaskan bagaimana kandidat dapat mengartikulasikan visi dan misi serta penguasaan tema pada debat. Subtema dalam debat terakhir membahas mengenai program kerja, pasangan Ahok-Djarot yang notabene adalah petahana mampu menjelaskan tema tersebut dikarenakan program-program kerja yang mereka susun telah dilaksanakan.

Kedua, strategi untuk mengkritik posisi lawan. Pasangan Ahok-Djarot dengan sangat lugas mengkritik program-program kerja yang disusun oleh pasangan Anies-Sandi pada debat terakhir. Hal yang menjadi perhatian pasangan Ahok-Djarot adalah mekanisme rumah tanpa DP 0 Persen yang juga menjadi perhatian masyarakat Jakarta. Maka dari itu, sebagian masyarakat Jakarta memandang sebelah mata salah satu program kerja Anies-Sandi.

Terakhir, kandidat menggunakan bahasa verbal maupun nonverbal. Ketika Debat Pilkada putaran terakhir dilaksanakan, penampilan Basuki Tjahja Purnama di setiap debat yang dilakukan oleh KPUD DKI Jakarta dinilai lebih unggul dibanding Anies Baswedan. Dalam setiap debat, Ahok dapat menjelaskan setiap visi dan misi serta memaparkan program-program kerja yang ia susun dengan Djarot Saeful Hidayat dengan sangat baik dan dapat dimengerti masyarakat luas.

Fenomena-fenomena yang terjadi sepanjang Pilkada DKI Jakarta 2017 sangat banyak. Salah satunya adalah informasi bohong yang beredar di media sosial pun tak luput dari perhatian. Infografis di atas yang dibuat oleh www.kumparan.com, terdapat 5 berita hoax salah satunya adalah isu KTP ganda. Faktanya, KTP ganda yang beredar semua foto KTP tersebut dipalsukan oleh oknum tertentu. Pasca kekalahan Ahok-Djarot pada Pilkada DKI Jakarta 2017, masyarakat Jakarta yang mendukung AhokDjarot mengirimkan karangan bunga. Karangankarangan bunga tersebut tidak hanya datang dari pendukung mereka yang tinggal di Jakarta tetapi di seluruh Indonesia, bahkan pendukung mereka yang berada di luar negeri.

Lalu, fenomena yang mendapat perhatian masyarakat adalah saat Basuki Tjahja Purnama 
divonis dua tahun penjara atas kasus penistaan agama. Hakim Pengadilan Negeri Jakarta Pusat pada 9 Mei 2017 memutuskan Ahok bersalah dan divonis dua tahun penjara. Hal tersebut membuat para pendukungnya kecewa dan netizen di media sosial khususnya di twitter bereaksi. Kekalahan AhokDjarot diartikan oleh para pendukung bukanlah akhir dari segalanya. Dalam konteks debat terakhir pada tanggal 12 April 2017, reaksi yang ditimbulkan masyarakat khususnya yang menggunakan media sosial seperti twitter sangatlah tinggi.

Jika dikaitkan lebih jauh mengenai fenomena opini-opini yang beredar terkait Pilkada DKI Jakarta 2017, pemerintah sudah mengatur UUD ITE untuk para pengguna media massa dan media sosial untuk menjunjung etika dalam menggunakan media massa dan akun media sosial mereka. Pada bulan November 2016, pemerintah resmi merevisi UUD ITE Nomor 11 Tahun 2008 menjadi UUD ITE Nomor 19 Tahun 2016. Terdapat dua pasal yang menyinggung tindakan menyuarakan kebencian dan penghinaan SARA yaitu pasal 45 dan 45A. Pasal 45 berbunyi:

"Setiap orang yang dengan sengaja dan tanpa hak mendistribusikan dan/atau mentransmisikan dan/atau membuat dapat diaksesnya Informasi Elektronik dan/atau Dokumen Elektronik yang memiliki muatan penghinaan dan/ atau pencemaran nama baik sebagaimana dimaksud dalam Pasal 27 ayat (3) dipidana dengan pidana penjara paling lama 4 (empat) tahun dan/atau denda paling banyak Rp 750.000.000,00 (tujuh ratus lima puluh juta rupiah)."

\section{Adapun Pasal 45A ayat 2 berbunyi:}

"Setiap orang yang dengan sengaja dan tanpa hak menyebarkan informasi yang ditujukan untuk menimbulkan rasa kebencian atau permusuhan individu dan/atau kelompok masyarakat tertentu berdasarkan atas suku, agama, ras, dan antargolongan (SARA) sebagaimana dimaksud dalam Pasal 28 ayat (2) dipidana dengan pidana penjara paling lama 6 (enam) tahun dan/atau denda paling banyak Rp 1.000.000.000,00 (satu miliar rupiah)."

Kedua pasal tersebut sangat jelas sanksi untuk para pengguna media sosial yang bertindak sesuai dengan ayat-ayat di atas namun mereka mengabaikan peraturan tersebut. Ujaran-ujaran kebencian yang beredar pun dapat menimbulkan perpecahan. Maka dari itu, perlu adanya sosialisasi terhadap masyarakat untuk pandai bermedia sosial dan memperhatikan etika dalam menggunakan akun media sosial mereka.

Pilkada DKI Jakarta 2017 telah berakhir, AniesSandi memenangkan pemilihan kepala daerah tersebut dengan memperoleh suara sebanyak 57,96\%, sedangkan Ahok-Djarot 42,04\%. Berdasarkan hasil survei yang dilakukan oleh lembaga survei Indikator Politik Indonesia yang dilansir www.tirto.id di atas menunjukkan bahwa faktor memilih gubernur yang paling utama adalah karena seagama.

Mayoritas masyarakat Jakarta beragama Islam, tentunya mereka memilih Anies-Sandi yang beragama Islam. Akibat sentimen agama, perpecahan pun terjadi. Para pemilih yang memilih Ahok-Djarot dilabelkan sebagai individu yang munafik. Lalu, terdapat beberapa masjid di DKI Jakarta membuat sebuah poster yang bertuliskan menolak mensholatkan pemilih Ahok-Djarot.

Faktor yang kedua adalah gaya bicara AniesSandi yang ramah dan santun. Gaya bicara tersebut sangat disukai oleh masyarakat Jakarta, berbeda dengan gaya bicara Basuki Tjahja Purnama yang mendapatkan respons negatif tetapi ada juga masyarakat Jakarta yang tidak mempermasalahkan gaya bicaranya. Faktor terakhir yang menjadi faktor kemenangan Anies-Sandi di Pilkada DKI Jakarta 2017 berdasarkan hasil survei Indikator Politik Indonesia, pemilih meyakini Anies-Sandi dapat membawa perubahan bagi Ibukota DKI Jakarta dengan programprogram yang mereka susun, yang mana programprogram tersebut lebih pro terhadap rakyat kecil.

Unsur SARA yang disuarakan oleh beberapa netizen untuk menyerang Ahok pun ramai diperbincangkan, beberapa netizen menyerang latar belakang etnis Ahok, yaitu etnis Tionghoa. Faktor kedua adalah langkah Ahok menata dan mengubah kota DKI Jakarta menimbulkan pro dan kontra di kalangan masyarakat, salah satu cara Ahok menata kota adalah dengan melakukan penggusuran ditambah dengan kedekatannya dengan pengembang. Ahok dituding tidak pro rakyat kecil dan tidak peduli dengan nasib mereka setelah aksi penggusuran dan melakukan proyek reklamasi.

Faktor terakhir adalah gaya bicara Ahok yang tidak disukai oleh masyakarat Jakarta karena terkadang gaya bicara Ahok tidak punya sopan santun. Ahok tidak mempedulikan perasaan individu yang ia tegur. Gaya bicara Ahok menganut gaya bicara yang low context atau gaya bicara yang langsung kepada sasaran tanpa melakukan pembicaraan yang basa-basi sedangkan pasangan Anies-Sandi menganut gaya bicara high context. Fenomena di 
atas menunjukkan bahwa konsultan politik serta aktor-aktor politik yang berafiliasi terhadap kedua kandidat sangat berperan dalam menyusun strategi untuk memenangkan suatu pemilihan umum.

Pasca kekalahan Ahok-Djarot pada Pilkada DKI Jakarta 2017, masyarakat Jakarta yang mendukung Ahok-Djarot mengirimkan karangan bunga. Karangankarangan bunga tersebut tidak hanya datang dari pendukung mereka yang tinggal di Jakarta tetapi di seluruh Indonesia, bahkan pendukung mereka yang berada di luar negeri. Lalu, fenomena yang mendapat perhatian masyarakat adalah saat Basuki Tjahja Purnama divonis dua tahun penjara atas kasus penistaan agama. Hakim Pengadilan Negeri Jakarta Pusat pada tanggal 9 Mei 2017 memutuskan Ahok bersalah dan divonis dua tahun penjara. Hal tersebut membuat para pendukungnya kecewa dan netizen di media sosial khususnya di twitter bereaksi.

Muncul hashtag atau tagar \#SaveAhok ketika vonis itu dilayangkan. Kemudian, para pendukung Basuki Tjahja Purnama mengadakan Aksi Seribu Lilin untuk Ahok. Fenomena Aksi Seribu Lilin juga tidak hanya digelar di Jakarta, tetapi di beberapa daerah di Indonesia maupun di luar negeri. Fenomena pengiriman karangan bunga ke kantor Balai Kota DKI Jakarta dan Aksi Seribu Lilin yang dilakukan oleh pendukung Basuki Tjahja Purnama dan Ahok Djarot di beberapa kota di Jakarta maupun luar negeri menunjukkan bahwa dukungan moral tetap akan digaungkan oleh para pendukungnya.

Kekalahan Ahok-Djarot diartikan oleh para pendukung bukanlah akhir dari segalanya. Dalam konteks debat terakhir pada tanggal 12 April 2017, reaksi yang ditimbulkan masyarakat khususnya yang menggunakan media sosial seperti twitter sangatlah tinggi. Reaksi netizen tidak hanya terlihat pada debat terakhir tetapi ketertarikan netizen telah terlihat pada saat debat pertama yang diselenggarakan oleh KPUD DKI Jakarta. Dahulu, pada Pilkada DKI Jakarta sebelumnya, netizen tidak terlalu peduli dengan debat yang diselenggarakan oleh KPUD DKI Jakarta karna tidak ada isu yang menjadi perbincangan di masyarakat.

Jika dikaitkan dengan kasus penistaan agama yang dilakukan oleh Basuki Tjahja Purnama, mayoritas warga Jakarta yang beragama Islam menentang dengan sangat keras perbuatan yang dilakukan oleh Ahok. Tidak hanya warga Jakarta saja yang bereaksi tetapi warga di luar DKI Jakarta juga mengungkapkan kekecewaan mereka. Sedangkan kaum minoritas hanya bisa berdiam karena suara atau pendapat mereka akan mendapatkan pertentangan dari kaum mayoritas.

Kaum minoritas dapat dikatakan sebagai pendukung Basuki Tjahja Purnama dan Djarot Syaiful Hidayat. Mereka tidak dapat berbicara banyak dikarenakan para pendukung Anies-Sandi yang didominasi oleh kaum Muslim akan menentang opini-opini mereka. Sebagian kaum mayoritas pun mengklaim jika ada individu yang membela penista agama (Basuki Tjahja Purnama) maka individu tersebut dapat dikatakan sebagai individu yang inkonsisten. Akibatnya, seseorang yang mendukung Ahok-Djarot lebih memilih untuk diam dibandingkan bersuara agar tidak terjadi perdebatan.

\section{SIMPULAN}

Penelitian ini menyimpulkan bahwa debat terakhir Pilkada DKI Jakarta 2017 yang dilaksanakan pada 12 April 2017 mendapatkan banyak perhatian dari para pengguna media sosial khususnya di twitter. Hashtag \#DebatPilkadaDKI pada debat terakhir menjadi wadah untuk menyuarakan pendapat. Beragam opini pun muncul tetapi yang menjadi perbincangan paling hangat adalah opiniopini pengguna twitter mengenai SARA dan program kerja.

Berdasarkan hasil temuan penelitian, arah opini berdasarkan hashtag \#DebatPilkadaDKI, arah opini positif lebih banyak didapatkan oleh pasangan AhokDjarot. Sedangkan, arah opini negatif lebih banyak didapatkan oleh pasangan Anies-Sandi. Netizen yang mengutarakan opini-opini positif untuk pasangan Ahok-Djarot dikarenakan menganggap pasangan nomor dua lebih mampu menjelaskan masalahmasalah yang ada di DKI Jakarta serta mampu memaparkan program kerja yang lebih dapat dipahami.

Selain itu, opini-opini yang didapatkan oleh pasangan nomor dua, yaitu Basuki Tjahja Purnama dan Djarot Syaiful Hidayat, selama debat terakhir berlangsung dibumbui opini-opini SARA. Isu SARA muncul dikarenakan kasus yang menimpa Basuki Tjahja Purnama alias Ahok, pengguna twitter tidak hanya melabelkan Ahok sebagai seorang penista agama Islam namun mereka pun menyerang etnis Ahok, yaitu etnis Tionghoa. Pasangan nomor tiga Anies-Sandi pun tak luput dari perbincangan pengguna media sosial di twitter pada saat debat terakhir berlangsung. Opini-opini yang muncul lebih banyak mengkritik program kerja yang dikemukakan oleh pasangan tersebut terutama program kerja OK OCE dan rumah tanpa DP $0 \%$. 
Selain itu, pengguna juga mempertanyakan integritas dari Anies Baswedan dan Sandiaga Uno. Mereka berpendapat bahwa Anies-Sandi belum bisa dijadikan pemimpin untuk mengatur kota DKI Jakarta, pengguna pun juga mempertimbangkan kinerja Anies Baswedan yang dahulu gagal menjadi Menteri Pendidikan. Para pendukung Anies-Sandi juga tak luput dari sorotan para netizen. Anies-Sandi didukung oleh slaah satu ormas Islam yaitu FPI (Front Pembela Islam). Netizen menilai FPI sebagai ormas Islam yang radikal, kekecewaan mereka tak terbendung ketika Anies Baswedan bersandang ke markas FPI pada bulan November 2016.

Hasil pemungutan suara putaran kedua Pilkada DKI Jakarta 2017, Anies-Sandi memenangkan pertarungan dengan memperoleh suara sebanyak $57,96 \%$. Hal tersebut dapat terjadi karena sifat pemilih yang dinamis, pemilih mempunyai beberapa pertimbangkan sampai akhirnya mereka memutuskan untuk memilih antara kandidat nomor dua atau nomor tiga. Lalu, opini-opini berbau kebencian maupun penghinaan banyak dikemukakan oleh pengguna twitter.

Para pengguna twitter seakan lupa bahwa terdapat UU ITE yang sudah mengatur hal-hal yang tidak diperbolehkan dalam menyampaikan suatu pesan atau informasi yang beredar di media massa maupun media sosial. Etika bermedia sosial harus terus digaungkan agar para pengguna media sosial dapat menggunakan akun media sosial mereka dengan baik dan benar agar tidak merugikan orang lain.

\section{DAFTAR PUSTAKA}

Arifin, A. (2008). Opini Publik. Jakarta: Pustaka Indonesia.

Correia, J. C., \& Maia, R. C. (2011). Public Sphere Reconsidered. Covilha: Livros Labcom.

Donsbach, W. \& Traugott, M.W. (2008). Public Opinion Research. London: Sage Publications Ltd.

Eriyanto. (2011). Analisis Isi: Pengantar Metodologi Untuk Penelitian IImu Komunikasi dan IImu-ilmu Sosial Lainnya. Jakarta: Kencana.

Fortner, S.R. \& Fackler, P.M. (2014). The Handbook of Media and Mass Communication Theory. Volume 1. West Sussex: John Wiley and Sons, Inc.

Gainous, J. \& Wagner, K.M. (2014). Tweeting to Power: The Social Media Revolution In American Politics. New York: Oxford University Press.
Juditha, C. (2014). Opini Publik Terhadap Kasus “KPK Lawan Polisi" dalam Media Sosial Twitter. Jurnal Pekommas, 17(2): 61-70.

Neuman, W.L. (2016). Metode Penelitian Sosial Pendekatan Kualitatif dan Kuantitatif (Edisi 7). Jakarta: Indeks.

Nimmo, D. (2010). Komunikasi Politik: Khalayak dan Efek. (Tjun Sujarman, Penerjemah). Bandung: Remaja Rosdakarya.

Patrut, B. \& Patrut, M. (2014). Social Media in Politics. London: Singer.

Perloff, M.R. (2008). Political Communication: Politics, Press, and Public In America. New York: Routledge.

Subiakto, H., \& Ida, R. (2012). Komunikasi Politik, Media, dan Demokrasi, Edisi Ke-2. Jakarta: Kencana.

Taprial, V. \& Kanwar, P. (2012). Understanding Media Social. Frederiksberg: Ventus Publishing.

Weller, K., et.al. (2014). Twitter and Society. New York: Peter Lang Publishing. 